\title{
New data on spiders (Arachnida: Aranei) of East Kazakhstan
}

\author{
Новые данные о пауках (Arachnida: Aranei) \\ Восточного Казахстана
}

\author{
Alexander A. Fomichev ${ }^{1,2}$ \& Yuri M. Marusik ${ }^{3,4}$ \\ А.А. Фомичев, Ю.М. Марусик
}

\footnotetext{
${ }^{1}$ Novosibirsk State Pedagogical University, Vilyuiskaya 28, Novosibirsk630126 Russia. E-mail: a.fomichov@mail.ru

${ }^{1}$ Новосибирский государственный педагогический университет, Вилюйская 28, Новосибирск 630126 Россия.

${ }^{2}$ Siberian Zoological Museum, Institute of Systematics and Ecology of Animals, SB RAS, Frunze str., 11, Novosibirsk 91, 630091 Russia.

${ }^{2}$ Сибирский Зоологический Музей, Институт Систематики и Экологии Животных, СО РАН, Фрунзе 11 , Новосибирск 91 , 630091 Россия.

${ }^{3}$ Institute for Biological Problems of the North, RAS, Portovaya Str. 18, Magadan 685000, Russia. E-mail: yurmar@mail.ru

${ }^{3}$ Институт биологических проблем Севера ДВО РАН, Портовая 18, Магадан 685000. Россия.

${ }^{4}$ Zoological Museum, University of Turku, FI-20014 Turku, Finland.

4 Зоологический музей, Университет Турку, FI-20014 Турку, Финляндия.
}

KEY WORDS: East Kazakhstan, Aranei, spiders, new species, new distribution records.

КЛЮЧЕВЫЕ СЛОВА: Восточный Казахстан, Aranei, пауки, новый вид, новые находки.

ABSTRACT. A list of 65 spider species (excluding unidentified) collected in East Kazakhstan Region in 2011 and 2012 is provided. A new species, Zaitunia zonsteini sp.n. ( $(+)$. is described. 19 species are recorded for East Kazakhstan for the first time, including 3 species new to the Kazakhstan Republic. Poorly known species Pardosa italica Tongiorgi, 1966, and one unidentified-to-genus-level species (family Gnaphosidae) are illustrated.

РЕЗЮМЕ. Приводится обзор 65 видов (исключая неопределённых) собранных в Восточном Казахстане в 2011 и 2012 гг. Описан новый вид Zaitunia zonsteini sp.n. (). 19 видов отмечены в Восточном Казахстане впервые, из них 3 вида впервые отмечены для Республики Казахстан. Иллюстрирован малоизвестный вид Pardosa italica Tongiorgi, 1966 и один неопределённый до рода вид из семейства Gnaphosidae.

\section{Introduction}

The spider fauna of East Kazkahstan Region is relatively well studied owing to numerous publications [Savelyeva, 1970, 1972a,b,c, 1976, 1979, 1984b, Marusik et al., 1990; Ovtsharenko, Savelyeva, 1992; Marusik, Tarabaev, 1991; Utochkin, Savelyeva, 1995; Eskov, Marusik, 1995; Logunov, Marusik, 2000, 2003; Tuneva, 2004; Marusik, Esyunin, 2010; Marusik, Logunov, 2011, etc.]. Up to now about 420 species are reported from this area (personal calculations) and 879 species are known in the whole Kazakhstan [Mikhailov, 2013]. Although number of species known in the region exceeds those known in Uzbekistan (330), Tajiki- stan (318), Kyrgyzstan or Turkmenistan (391) [Mikhailov, 2013], the spider fauna remains inadequately studied. Two relatively short collecting trips made in 2011 and 2012 revealed 19 species new to the East Kazakhstan Region, three species new to all of Kazakhstan and even several species new to science. The main goals of this paper are to provide data about species collected in East Kazakhstan Region with special emphasis on new records and description of new species.

\section{Material and Methods}

This paper based materials collected by the senior author (AF) and A.N. Litvinov (AL) during the joint field trip to East Kazakhstan in June 30 - July 17, 2011, and several specimens collected by Litvinov in July - August 2011 and July - August 2012. Material was collected in SW part of the West Tarbagatai Mountain Range and Kyzylbel'tau Mountains which are part of the Kazakhstan Melkosopochnik (hills). Both mountain ranges have rather xeric climate and the most widespread habitats in the region are stony steppes with rocks and bushes. Forests are almost absent. And few trees grow in rivers valleys only. The list of localities and habitats is given below. Seven unidentified species are not mentioned in the list.

In the list of collected spiders each species name is followed by a number (in parentheses) corresponding to the locality and by a letter corresponding to the habitat in which it was collected. Species new to the Kazakhstan Republic are marked with two asterisks $(* *)$ and those new to the East Kazakhstan Region are marked by one asterisk (*). Photographs were taken in 


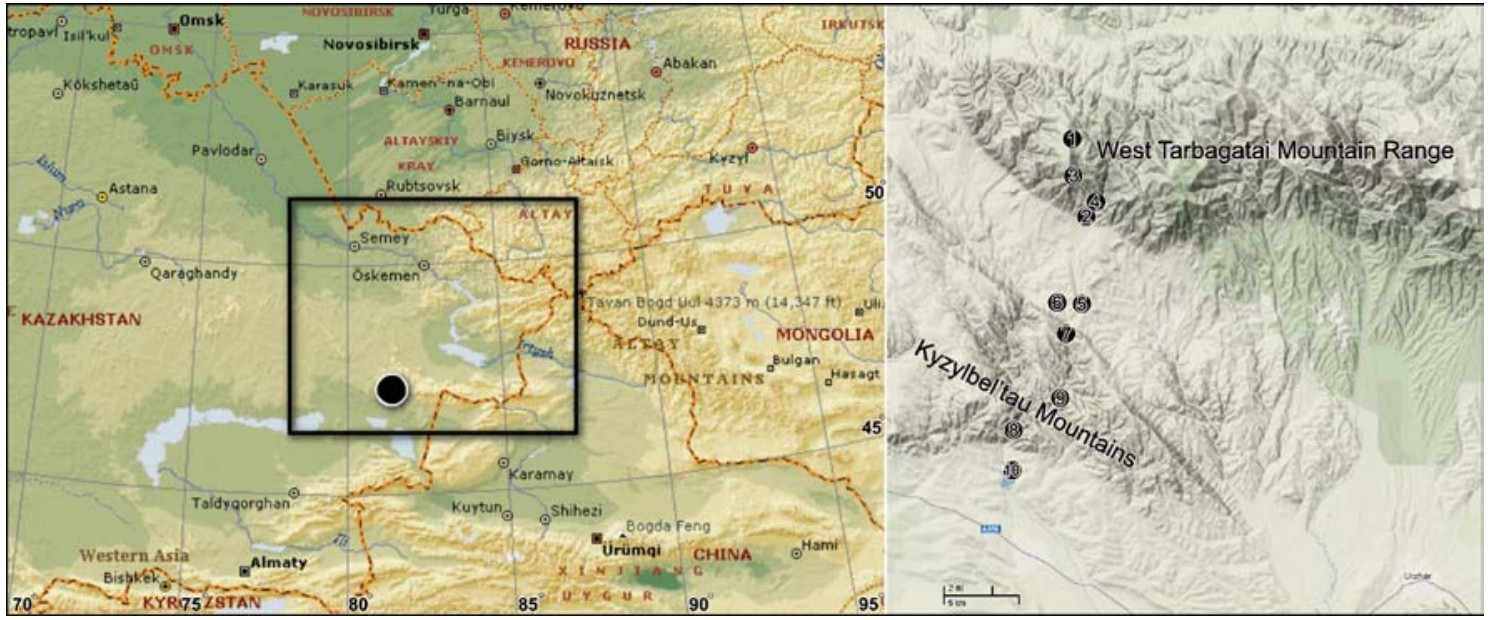

Map. Geographical position of the study area showing exact collecting localities.

Карта. Географическое положение исследуемой области и точки сбора.

dishes of different sizes with paraffin at the bottom. Specimens were photographed using an Olympus Camedia E-520 camera attached to an Olympus SZX16 stereomicroscope at the Zoological Museum, University of Turku and an AxioCam MRc5 (Zeiss) camera attached to a Stemi 2000 - C stereomicroscope. SEM microphotographs were made with a JEOL JSM-5200 in the Zoological Museum, University of Turku. Digital images were prepared using "CombineZP" and "Helicon focus 3.10" image stacking software. Epigynes were macerated in $10 \% \mathrm{KOH}$ solution and painted with methylene blue. All measurements are given in millimetres. Material will be deposited in the collection of Institute of Systematics and Ecology of Animals, Novosibirsk, Russia (ISEA).

Localities:

1) Urdzhar District, SW part of West Tarbagatai Mountain Range, Sandyktas Mt., $47^{\circ} 21^{\prime} \mathrm{N}, 81^{\circ} 18^{\prime} \mathrm{E}$, 1800-1900 m, 6.07.2011, AF \& AL.

2) Same district, SW part of West Tarbagatai Mountain Range, $47^{\circ} 18^{\prime} \mathrm{N}, 81^{\circ} 19^{\prime} \mathrm{E}$, near Terekty (Blagodatnoe) Village, $1200 \mathrm{~m}, 3-17.07 .2011$, AF \& AL.

3) Same district, $47^{\circ} 19^{\prime} \mathrm{N}, 81^{\circ} 18^{\prime} \mathrm{E}, 1600-1800 \mathrm{~m}$, 6-7.07.2011, AF \& AL.

4) Same district, Terekty River gorge, $47^{\circ} 18^{\prime} \mathrm{N}$, $81^{\circ} 19^{\prime} \mathrm{E}, 1200 \mathrm{~m}, 6-7.07 .2011$, AF \& AL.

5/1) Same district, between West Tarbagatai Mountain Range and Kyzylbel'tau Mountains, Terekty (Blagodatnoe) Village, $47^{\circ} 15^{\prime} \mathrm{N}, 81^{\circ} 19^{\prime} \mathrm{E}, 900 \mathrm{~m}, 1-11.07$. 2011, AF.

5/2) Same district, same place, 07-08.2011 and 2012, AL

6) Same district, vicinities of Terekty (Blagodatnoe) village $47^{\circ} 15^{\prime} \mathrm{N}, 81^{\circ} 18^{\prime} \mathrm{E}, 900-1000 \mathrm{~m}, 2-5.07$. 2011, AF \& AL.

$7 / 1$ ) Same district, Kyzylbel'tau Mountains $47^{\circ} 14^{\prime} \mathrm{N}$, $81^{\circ} 18^{\prime} \mathrm{E}$ (near SW part of West Tarbagatai Mountain Range), near Terekty (Blagodatnoe) village, 900-1000 m, 30.06-17.07.2011, AF \& AL.
7/2) Same district, same place, $1000 \mathrm{~m}, 07.2012$, AL.

7/3) Same district, unspecified locality in the Kyzylbel'tau Mountains, 900-1000 m, 07-08.2012, AL.

8) Same district, Kyzylbel'tau Mountains, 8-10 km SSW from Terekty (Blagodatnoe) village, Eginsu River gorge $47^{\circ} 10^{\prime} \mathrm{N}, 81^{\circ} 15^{\prime} \mathrm{E}, 600 \mathrm{~m}, 13.07 .2011$, AF \& AL.

9) Same district, 5-8 km SSW from Terekty (Blagodatnoe) village, Terekty River gorge $47^{\circ} 11^{\prime} \mathrm{N}, 81^{\circ}$ 18'E, 700-800 m, 13.07.2011, AF \& AL.

10) Same district, $3 \mathrm{~km} \mathrm{~N}$ from Zhana-Tilek (Juzhnyj) village, east bank of water reservoir on the Eginsu River $47^{\circ} 09^{\prime} \mathrm{N}, 81^{\circ} 15^{\prime} \mathrm{E}, 600 \mathrm{~m}, 12.07 .2011$, AF \& AL.

Habitats:

A. Mountain stony steppe with rocky outcrops (hand picking and sweeping, or only hand picking).

B. Mountain stony steppe with rocky outcrops and bushes (hand picking).

C. Steppe meadow (sweeping).

D. Reeds (hand picking).

E. Among stone blocks on the bottom of river gorge (hand picking).

F. Branches of trees hanging over river (hand picking).

G. Forest along river (sweeping).

H. Meadow near river (sweeping and hand picking).

I. Pebbly river bank (hand picking).

J. Grassy river bank (pitfall traps).

$\mathrm{K}$. Thickets of bushes (hand picking).

L. Stony outcrops among bushes (hand picking).

M. Rocky outcrops on the bottom of gorge (hand picking).

N. Pebbly river bank with drift in gorge (hand picking).

O. Clay shore of water reservoir (hand picking).

P. In building (hand picking).

Q. In garden (hand picking).

R. Agricultural fields (hand picking). 


\section{Description of new species}

\section{Zaitunia zonsteini sp.n.}

Figs 1-9, 12-14.

MATERIAL. Holotype + , KAZAKHSTAN, East Kazakhstan Region, Urdzhar District, Kyzylbel'tau Mountains, near Terekty (Blagodatnoe) Village $\left(47^{\circ} 14^{\prime} \mathrm{N}, 81^{\circ} 17^{\prime} \mathrm{E}\right)$, mountain stony steppe with rocky outcrops, $1000 \mathrm{~m}, 3-5.07 .2011$ (A.A. Fomichev, A.N Litvinov); Paratypes: 7 우, together with holotype; 2 우, same locality, 07.2012 (A.N. Litvinov); 2 우, same locality $\left(47^{\circ} 14^{\prime} \mathrm{N}\right.$, $81^{\circ} 18^{\prime} \mathrm{E}$ ), mountain stony steppe with rocky outcrops, $1000 \mathrm{~m}$, 2.07.2011 (A.A. Fomichev); 1 , same locality $\left(47^{\circ} 13^{\prime} \mathrm{N}, 81^{\circ} 18^{\prime} \mathrm{E}\right.$ ), mountain stony steppe with rocky outcrops, $900 \mathrm{~m}, 15.07 .2011$ (A.A. Fomichev); 1 ㅇ, SW part of West Tarbagatai Mountain Range $\left(47^{\circ} 18^{\prime} \mathrm{N}, 81^{\circ} 19^{\prime} \mathrm{E}\right)$, near Terekty (Blagodatnoe) Village, mountain stony steppe with rocky outcrops, $1200 \mathrm{~m}, 3.07 .2011$ (A.A. Fomichev, A.N. Litvinov).

All specimens were collected by hand picking. Holotype and paratypes are deposited in the Siberian Zoological Museum, Novosibirsk (ISEA).

ETYMOLOGY. The species named after our friend and colleague Sergei L. Zonstein (Tel Aviv), a world expert in Filistatidae.

DIAGNOSIS. The new species well differs from $Z$. inderensis Ponomarev, 2005 (Figs 10-11, 15), a single species known from Kazakhstan by having a clearly distinguishable pattern on the carapace and abdomen (a less pronounced or lacking a pattern in Z. inderensis), thinner macrosetae on the carapace (cf. Figs 3-5 and 10-11) and having two pairs of receptacles (one pair in Z. inderensis). Zaitunia zonsteini sp.n. differs considerably from Z. schmitzi (Kulczyñski, 1911), the type species of the genus by having receptacula of equal size (inner pair smaller than outer pair in $Z$. schmitzi [cf. Fig. 10 in Zonstein, 2009]. In addition all receptacles in new species have separate stems, while in Z. schmitzi receptacles in each side are on a common stem. The new species differs strongly from the two species from Iran, Z. persica Brignoli, 1982, and Z. alexandri Brignoli, 1982, by having two pairs of receptacles (one pair in Iranian species) [cf. Brignoli, 1982]. Pattern and endogyna in other Zaitunia species remain unknown.

DESCRIPTION. Female. Total length 3.3-3.4, carapace 1.2-1.7 long, 1.0-1.25 wide. Carapace from yellow to yellow brownish, with a distinct median band (Figs 3, 5) or median spot (Fig. 4). Some specimens have a thin dark continuous marginal stripe (Fig. 1-2, 3-5), or stripe developed in the cephalic part (Fig. 5), or it may be totally lacking in pale specimens (Fig. 4). There are some setae on carapace. Eye tubercle dark, clypeus dark. Sternum, labium and maxilla yellow, maxilla somewhat lighter. Chelicera yellowish brown. Legs light yellow. Metatarsi and tarsi darker than other articles. Palpal femora and patellae light yellow, tibiae slightly darker and tarsi light brown. Abdomen dorsally light yellow with variable brown pattern (Figs 3-5) or sometimes pattern lacking. Abdomen ventrally yellow with light brown pattern near spinnerets (Fig. 6). Eye sizes and interdistances: AME 0.06; ALE 0.13; PLE 0.09; PME 0.08; AME - AME 0,04; ALE - AME
0,03; ALE - PLE 0,04; PLE - PME 0,03; PME - PME 0,12 . Leg formula 1423 . Spination variable, even left and right leg sometimes have different spination. All femora with one dorsal spine (d1-0-0), tibia I-III with one spine (v0-1-0) or spines are lacking; tibia IV with two ventral spines (v0-2-0). Spination on metatarsi more variable: I v2-2(1)-3 or v2-0-3, II v2-3-3 or v2-03 , III v2-2-3 or v1-1-3, IV v1-3-3 or v1-2(1)-3. Tibia and metatarsus III may have dorsal spine.

Palpal femur with one dorsoapical spine, tarsi with three small ventral spines. Cribellum as shown on Fig. 6. Calamistrum formed by short row of setae placed in small depression (Figs 7-9).

Endogyna as in Figs 12-14, with two pairs of receptacula; each receptaculum with small wrinkled stem; all receptacula have independent stems.

Male. Unknown.

DISTRIBUTION. Only the type locality.

BIOLOGY. The new species lives under stones (on the undersides of the stones). Webs looks like irregular mesh of threads. Grey egg sacs are attached to the lower surface of stones.

COMMENTS. Zaitunia Lehtinen, 1967 is small genus of Filistatinae spiders with nine species distributed from Egypt to Tajikistan, and north to northwestern Kazakhstan. Only the type species of the genus, $Z$. schmitzi, is known by male and female sexes all other species are known by the females only. According to Zonstein [2009] Central Asian species seem to belong to a separate genus and are misplaced in Zaitunia. The new species extends the known range of the genus about $10^{\circ}$ to the East. Together with $Z$. inderensis Ponomarev, 2005 known from West Kazakhstan (about $48^{\circ} 33^{\prime} \mathrm{N}, 52^{\circ} 00^{\prime} \mathrm{E}$ ), the new species forms the northern limit of distribution of the genus and whole family in the Palaearctic.

\section{List of species}

\section{AGELENIDAE (1)}

Agelena labyrinthica Clerck, 1758: 1 [6k].

\section{ARANEIDAE (8)}

Araneus alsine (Walckenaer, 1802): 1 ㅇ [5/2]. [5/2q]

Araneus diadematus Clerck, 1758: 3 우 [5/2], $10^{7}$ Ara

$\sigma^{7}[5 / 1 \mathrm{~g}]$.

COMMENTS. Apparently it is a new species. It differs from Araniella species occurring in East Palaearctic.

Argiope bruennichi (Scopoli, 1772): 1 [5/2].

Larinioides ixobolus (Thorell, 1873): 1 ㅇ [5/2p]. 우 [4f $]$.

Larinioides patagiatus (Clerck, 1758): 1 \% [7/1f], 1

Mangora acalypha (Walckenaer, 1802): 1 + [7/1a], 2 우우 $[5 / 1 \mathrm{~h}]$. 


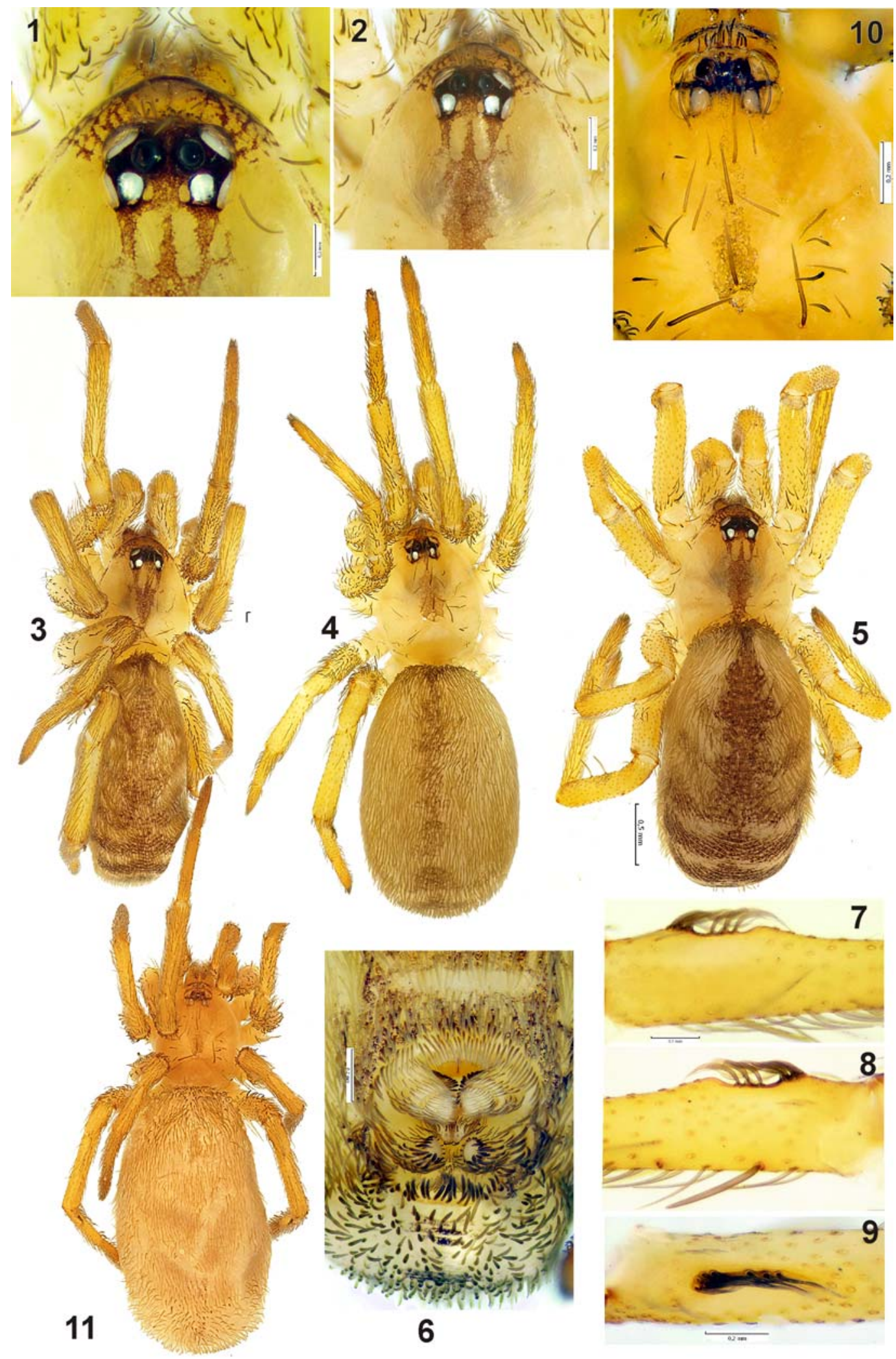

Figs 1-11. General appearance of Zaitunia zonsteini sp.n. (1-9) and Z. inderensis (10-11): 1-2, 10 - carapace, cephalic part, dorsal; 3-5, 11 - habitus, variation of pattern; 6 - spinnerets; 7-9 - calamistrum, prolateral, retrolateral and dorsal, respectively.

Рис. 1-11. Внешний вид Zaitunia zonsteini sp.n. (1-9) и Z. inderensis (10-11): 1-2, 10 - карапакс, головная часть, дорзально; 3-5, 11 - габитус, вариации окраски; 6 - паутинные бородавки; 7-9 - каламиструм, пролатерально, ретролатерально и дорзально, соответственно. 

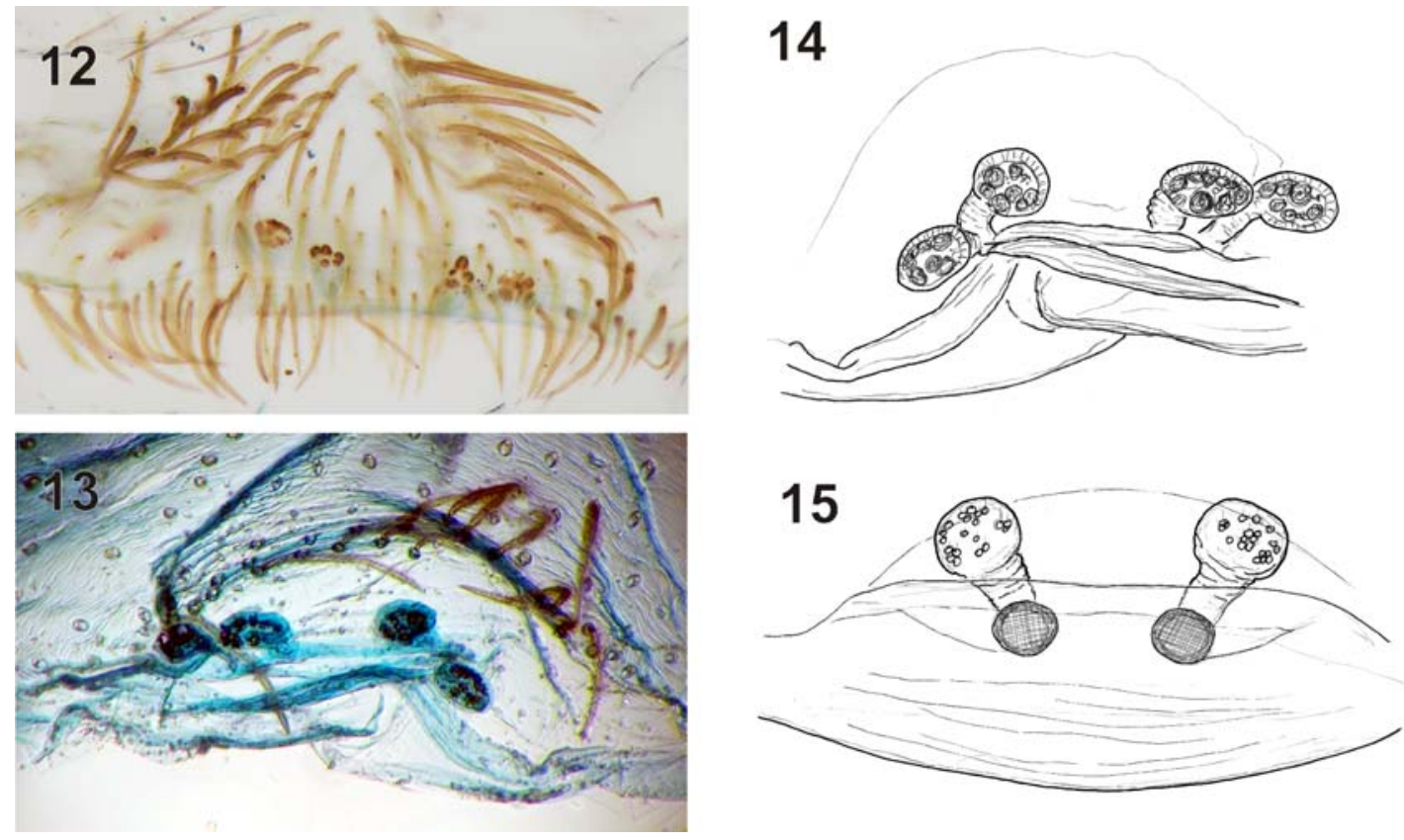

Figs 12-15. Female copulatory organs of Zaitunia zonsteini sp.n. (12-14) and Z. inderensis (15), dorsal. Рис. 12-15. Копулятивные органы самки Zaitunia zonsteini sp.n. (12-14) и Z. inderensis (15), сверху.

Neoscona adianta (Walckenaer, 1802): $10^{7}[7 / 1 \mathrm{c}]$, $1 \mathrm{O}^{\top}[5 / 1 \mathrm{~h}]$.

\section{CHEIRACANTHIIDAE (1)}

*Cheiracanthium punctorium (Villers, 1789): $10^{7}$ [4d], $2 O^{7} O^{7}[5 / 2]$.

COMMENTS. Although the species is known from Europe to South Siberia and Central Asia, it was not reported from East Kazakhstan Region before.

\section{CLUBIONIDAE (1)}

*Clubiona neglecta O. Pickard-Cambridge, 1862: $1 \mathrm{O}^{7}[5 / 1 \mathrm{~h}]$.

COMMENTS. Although this species has transPalaearctic nemoral range [Marusik et al., 2000] it was found in East Kazakhstan Region for the first time.

\section{DICTYNIDAE (1)}

Dictyna arundinacea (Linnaeus, 1758): $1 \bigcirc^{7}$ [5/1f].

\section{FILISTATIDAE (1)}

Zaitunia zonsteini sp.n. (see above): 11 우 [7/1a], 1 ㅇ [2a], 2 우 [7/2a].

\section{GNAPHOSIDAE (9)}

Gnaphosidae gen. sp.: $10^{7}$ [7/1a].

COMMENTS. We were unable to place this species in any known genus. Most likely, it is a new species belonging to a new genus. Habitus and male palp as in Figs 16-20.

Callilepis nocturna (Linnaeus, 1758): 1 [ [3a].

Drassodes cupreus (Blackwall, 1834): 4 우 [7/1a].

COMMENTS. One specimen was found in an ant nest under stone.

*Drassyllus lutetianus (L. Koch, 1866): 1 9 [7/1j].

COMMENTS. Although the species is known from Europe to Middle Siberia, it was not reported from East Kazakhstan Region before. [2a].

Gnaphosa licenti Schenkel, 1953: $10^{\top} 1$ 우 [6r], 1 ㅇ

*Gnaphosa steppica Ovtsharenko, Platnick et Song, 1992: 4 우 [7/1a], 10 우 [2a].

COMMENTS. Recorded from East Kazakhstan for the first time. Distributed in a steppe zone of Eurasia, from Turkey through Krasnodar area and Caucasus to Central Kazakhstan.

Gnaphosa taurica Thorell, 1875: 1 우 [7/1a], 2 우 [3a], 1 우 [1a], 5 우 [2a].

Nomisia aussereri (L. Koch, 1872): 1 \& [7/3].

Phaeocedus sp.: 2 우 [7/1a], 1 ㅇ [7/3].

COMMENTS. It is an undescribed species, a description of which will be given in separate paper dealing with survey of Phaeocedus.

\section{LYCOSIDAE (11)}

Alopecosa sp: 1 ㅇ [7/1a].

COMMENTS. This undescribed species is rather common in Southeastern Kazakhstan (Gromov, pers. comm.). It is a large wolf spider which was found in the long horizontal burrow that goes under a stone. 

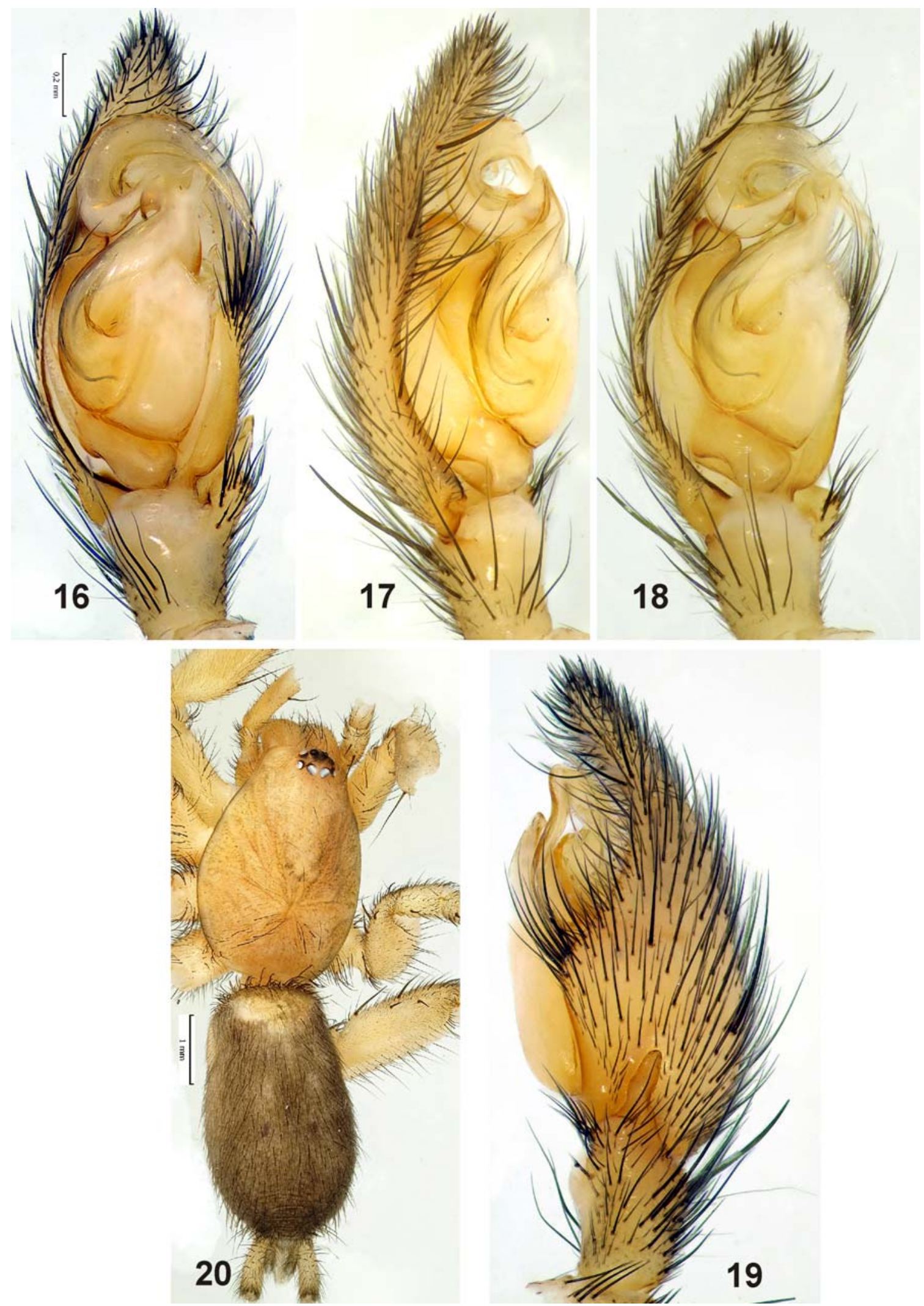

Figs 16-20. Male palp (16-19) and habitus (20) of Gnaphosidae gen. sp.: 16 - ventral; 17 - prolateral; 18 — ventro-prolateral; 19 - retrolateral; 20 - dorsal.

Рис. 16-20. Пальпа самца (16-19) и габитус (20) Gnaphosidae gen. sp.: 16 - вентрально; 17 — пролатерально; 18 вентрально-пролатерально; 19 - ретролатерально; 20 - дорзально. 
Alopecosa pulverulenta (Clerck, 1758): 1 \% [1a]. Alopecosa kazakhstanica Savelyeva, 1972: 1 \% [7/ 11], 1 [ [7/1a].

COMMENTS. Previously this species reported only from Ust-Kamenogorsk vicinities (Babkina Mel'nitsa village) in the north of East Kazakhstan. The new record represents the most southern locality of this species.

Pardosa agrestis (Westring, 1861): $1+[5 / 1 \mathrm{~h}], 1 \bigcirc^{7}$ [5/1j].

*Pardosa bifasciata (C.L. Koch, 1834): 9 ○० [1a], 3 oq [3a].

COMMENTS. Recorded from East Kazakhstan for the first time. Trans-Palaearctic boreo-nemoral range [Marusik et al., 2000]. $+[6 \mathrm{r}]$.

*Pardosa italica Tongiorgi, 1966 (?): $1 \bigcirc^{7}$ [10o], 1

COMMENTS. There are certain doubts about this species placement. We are not sure if it is a true Pardosa italica italica or P. italica valenta Zyuzin, 1976 (known from Ukraine) or P. jaikensis Ponomarev, 2007 (known from Daghestan and West Kazakhstan). Embolic division of $P$. italica and/or related species was never illustrated. At our request A.A. Nadolny compared our figures (Figs 22-25) of embolic division with specimens from the Crimea and found no differences. Females of $P$. italica (?) found in East Kazakhstan have epigyne clearly different from these from Northern Caucasus illustrated by Ponomarev et al. [2011: figs $66, \mathrm{~B}]$, but more similar to epigyne of $P$. jaikensis [cf. Ponomarev et al., 2011: fig. 5г], although our specimen has wider septal stem, apical pocket and septum itself. Male palp, epigyne and female habitus are as in Figs 21-28.

Pardosa fulvipes (Collett, 1876): $2 \sigma^{\top} \sigma^{\top} 1+[5 / 1 \mathrm{j}]$, 1 의 6 우 [5/1h], 8 우 [5/1g], 1 ㅇ [7/1j], 1 ㅇ [9n].

Pardosa lugubris (Walckenaer, 1802): 1 [5/1i], 1 q [9n].

*Pardosa paludicola (Clerck, 1758): 1 \% [5/1g].

COMMENTS. The first record for East Kazakhstan. Trans-Palearctic range.

Piratula hygrophila (Thorell, 1872): 1 † [9n], 2 $\sigma^{7} \sigma^{7} 12$ 우 [5/1i]. $2 \mathrm{q}]$.

*Xerolycosa miniata (C.L. Koch, 1834): $1 \sigma^{7}[5 /$

COMMENTS. Although the species has Euro-Mongolian boreo-nemoral range it has not been reported from the East Kazakhstan Region before.

\section{OXYOPIDAE (1)}

*Oxyopes lineatus Latreille, 1806: 4 + [5/1h].

COMMENTS. This is a first record of this species from East Kazakhstan Region and this record is the most northeastern in the range.

\section{PHILODROMIDAE (6)}

Philodromus cespitum (Walckenaer, 1802): 1 ○' [7/1i], 1 + [7/1c], 4 ○ $\bigcirc^{7} 2$ 우 [5/1h], 1 \% [5/2].
$[7 / 1 \mathrm{a}]$

**Thanatus arcticus Thorell, 1872: 1 \% [2a], 1 \%

COMMENTS. The present record is first for the Kazakhstan and southernmost in the whole range. According to [Marusik et al., 2000] this species has a Circum-Holarctic polyzonal range.

*Thanatus formicinus (Clerck, 1758): 1 \& [7/1c], 1 q [7/1a].

COMMENTS. Although the species has a circumHolarctic range it was not reported from East Kazakhstan Region before. This species was found in the same locality and even habitat as the closely related species, $T$. arcticus. Such co-habitation is unknown in other parts of the range (personal data).

*Thanatus oblongiusculus (Lucas, 1846): 1 + [5/ 1h], 2 o+ [7/1a].

COMMENTS. Reported from East Kazakhstan Region for the first time. The species is known from the Iberian Peninsula to Western China [Logunov, 1996].

Thanatus atratus Simon, 1875: 1 ㅇ [7/1a], 6 우 [2a]. Tibellus oblongus (Walckenaer, 1802): $1 \bigcirc^{\top}$ [5/1h].

\section{PISAURIDAE (1)}

*Pisaura mirabilis (Clerck, 1758): $1+$ [9h].

COMMENTS. This is a first record of the species in East Kazakhstan Region. It is known from Europe to Middle Siberia.

\section{SALTICIDAE (10)}

Aelurillus v-insignitus (Clerck, 1758): 1 [7/1a]. Heliophanus auratus C.L. Koch, 1835: $10^{7}$ [5/2]. Heliophanus patagiatus Thorell, 1875: $1+[4 \mathrm{e}]$. Heliophanus potanini Schenkel, 1963: 1 q [2a], 2 우 $[7 / 1 \mathrm{a}]$.

*Pellenes seriatus (Thorell, 1875): 1 \% [7/1a].

COMMENTS. Recorded in East Kazakhstan Region for the first time. The new record represents the easternmost locality in the range. This species has South European-Central Asian range [Logunov, Marusik, 2000].

Philaeus chrysops (Poda, 1761): 2 O $\sigma^{7} 5$ + +9 [7/ 1a], 2 우 [2a], 2 우 [4e], 2 우 [7/11].

*Phlegra bicognata Azarkina, 2004: 2 우 [7/1a].

COMMENTS. The species was found in East Kazakhstan Region for the first time and the present locality is easternmost in the range. It is known from South Ukraine to West Siberia [Azarkina, 2004a].

Phlegra profuga Logunov, 1996: 3 O+ [7/1a].

*Sitticus avocator (O. Pickard-Cambridge, 1885): $1 \sigma^{7}[7 / 1 \mathrm{a}]$.

COMMENTS. Our record is the first for East Kazakhstan Region and northernmost in the range.

Sitticus distinguendus (Simon, 1868): $2 \sigma^{\top} \sigma^{7}$ [8m].

\section{TETRAGNATHIDAE (3)}

Metleucauge dentipalpis Kronenberg, 1875: 2 우 [4f], 2 + + [9f].

Pachygnatha listeri Sundevall, 1830: $2+0$ [5/1j]. 

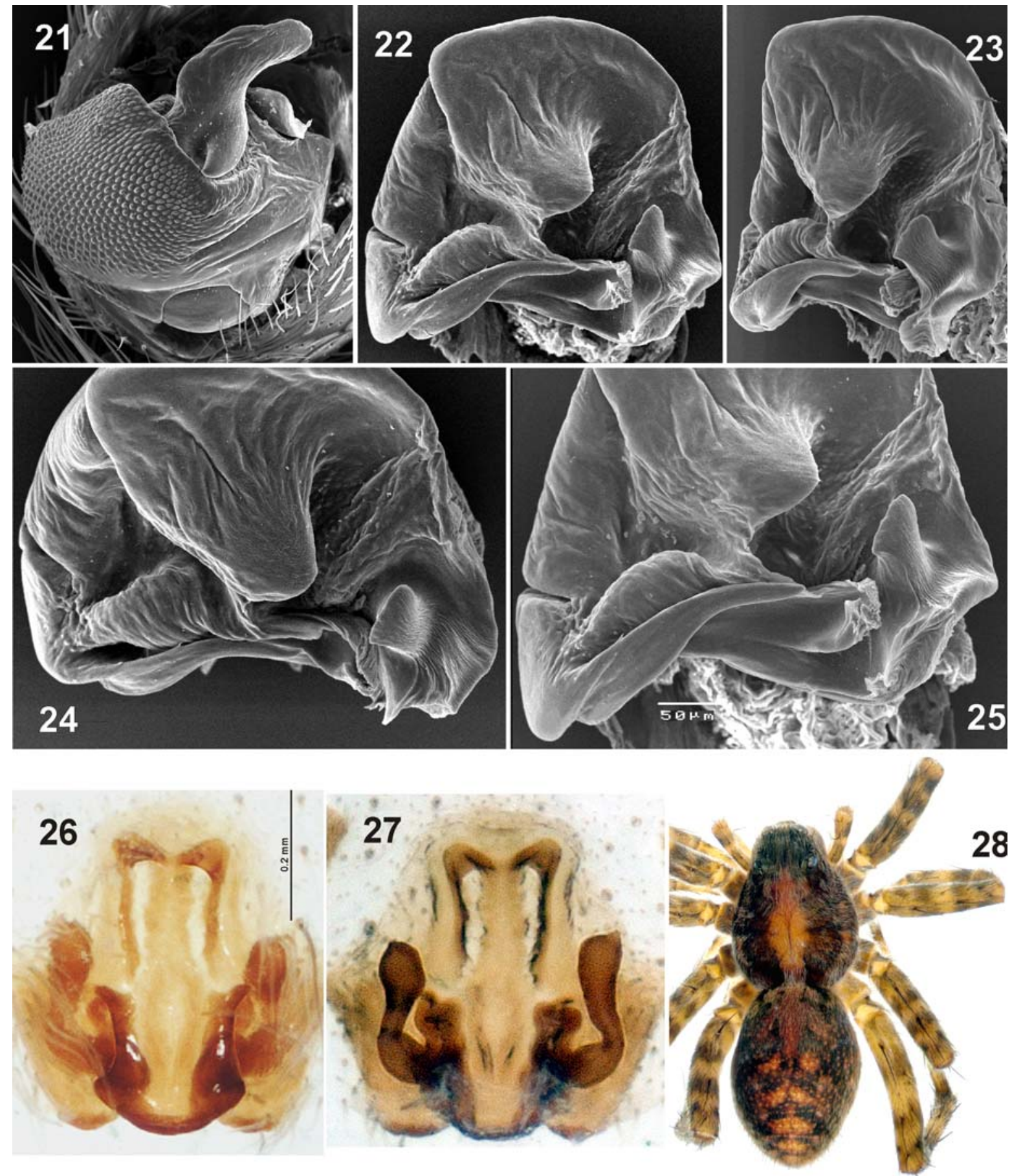

Figs 21-28. Copulatory organs and habitus of Pardosa italica (?): 21 - tegulum; 22-24 - embolic division, ventral, retrolateral and from above; 25 - part of embolic division, ventral; 26-27 — epigyne, ventral and dorsal; 28 - female habitus, dorsal.

Рис. 21-28. Копулятивные органы и габитус Pardosa italica (?): 21 - тегулюм; 22-24 - эмболюсный отдел, вентрально, ретролатерально и сверху; 25 - часть эмболюсного отдела, вентрально; 26-27 - эпигина, вентрально и дорзально; 28 - габитус самки, дорзально. $1 \mathrm{f}]$.

**Tetragnatha nigrita Lendl, 1886: $2 \bigcirc^{\top} \bigcirc^{\top} 1+[5 /$

COMMENTS. This species is new to Kazakhstan. It has trans-Palearctic nemoral range [Marusik et al., 2000]. It was reported by Logunov \& Gromov [2012] without indicating material and locality.

\section{THERIDIIDAE (3)}

Enoplognatha sp.: 1 \% [5/1h].

COMMENTS. Our specimen belongs to an undescribed species, which widely distributed in Kazakhstan (personal data). 
Steatoda albomaculata (De Geer, 1778): 3 우 [7/ 1a], 1 \% [3a].

Steatoda castanea (Clerck, 1758): $1+$ [5/2].

\section{THOMISIDAE (7)} $1 \mathrm{~h}]$.

Misumena vatia (Clerck, 1758): $1+[7 / 1 \mathrm{~b}], 1+[5 /$

Thomisus onustus Walckenaer, 1805: $1+$ [7/1a].

Xysticus bonneti Denis, 1938: 22 우 [1a] [3a].

Xysticus dzhungaricus Tyshchenko, 1965: 1 \% [3a], $1 \sigma^{7}[5 / 1 \mathrm{~h}]$.

*Xysticus minor Charitonov, 1946 (?): 1 \% [3a].

COMMENTS. There are some doubts about the placement of a singleton female. If our identification is correct, this species was found in East Kazakhstan Region for the first time. [7/1a].

Xysticus ninnii fusciventris Crome, 1965: $10^{\top} 1$ ㅇ

Xysticus pseudocristatus Azarkina et Logunov, 2001 (?): 1 + [7/1c].

\section{TITANOECIDAE (1)}

**Titanoeca asimilis Song et Zhu, 1985: 1 \& [1a], 1 + [3a], 3 O $^{7} 5$ 우 [7/1a].

COMMENTS. This is a species new to East Kazakhstan and Kazakhstan in whole. It was mentioned by Logunov \& Gromov [2012].

ACKNOWLEDGEMENTS. We thank colleagues who help us with this project: G.N. Azarkina (Novosibirsk, Russia) for providing a comparative material from the collections of the ISEA; A.V. Gromov (Almaty, Kazakhstan) for the help with identification of some species and providing information about spiders of Kazakhstan; S.L. Zonstein (University of Tel-Aviv, Israel) for advice on the taxonomy of Filistatidae; D.V Logunov (Manchester, UK) for the help with the identification of some Philodromidae and Salticidae; A.A. Nadolny (Simferopol, Ukraine) for the help with identification of Pardosa italica; G. Blagoev (Guelph, Canada) for providing a barcoding data. Special thanks are to A.N. Litvinov (Terekty, Kazakhstan) for organization of the field trip to East Kazakhstan Region and for being a great help in collecting. Also we thank R.Yu. Dudko (Novosibirsk, Russia) for providing facilities in the Institute of Systematics and Ecology of Animals. English of the final draft was kindly checked by R. Leech (Edmonton, Canada). This work was supported in part by the Russian Foundation for Basic Research (grants \#\# 11-0401716 and 12-04-01548).

\section{References}

Azarkina G.N. 2004. New and poorly known Palaearctic species of the genus Phlegra Simon, 1876 (Araneae, Salticidae) // Rev. arachnol. T.14. Fasc.6. P.73-108.

Brignoli P.M. 1982. [Contribution to the knowledge Palaearctic Filistatidae (Araneae)] // Rev. arachnol. T.4. P.65-75 [in French].

Eskov K.Yu., Marusik Yu.M. 1995. On the spiders from Saur Mt range, eastern Kazakhstan (Arachnida: Araneae) // Beitr. Araneol. Bd.4. S.55-94.
Logunov D.V. 1996. A critical review of the spider genera Apollophanes O. P.-Cambridge, 1898 and Thanatus C.L. Koch, 1837 in North Asia (Araneae, Philodromidae) // Rev. arachnol. T.11. Fasc.3. P.133-202.

Logunov D.V., Gromov A.V. 2012. Spiders of Kazakhstan. Manchester: Siri Scientific Press. 232 pp.

Logunov D.V., Marusik Yu.M. 2000. Catalogue of the jumping spiders of northern Asia (Arachnida, Araneae, Salticidae). Moscow: KMK Scientific Press. 300 p.

Logunov D.V., Marusik Yu.M. 2003. A revision of the genus Yllenus Simon, 1868 (Arachnida, Araneae, Salticidae). Moscow: KMK Scientific Press Ltd. 167 pp.

Marusik Yu.M., Esyunin S.L. 2010. On the northernmost Ajmonia Caporiacco, 1934 (Aranei: Dictynidae: Dictyninae) // Journal of Natural History. Vol.44. P. 361-367.

Marusik Yu.M., Logunov D.V. 2011. New faunistic records of spiders from East Kazakhstan (Arachnida: Aranei) // Arthropoda Selecta. Vol.20. No.1. P.57-63.

Marusik Yu.M., Logunov D.V., Koponen S. 2000. Spiders of Tuva, south Siberia. Magadan: IBPN FEB RAS. 252 pp.

Marusik Yu.M., Tarabaev Ch.K., Litovchenko A.M. 1990. [Catalogue of orb-weaving spiders (Aranei: Araneidae, Tetragnathidae, Uloboridae) of Kazakhstan. Family Araneidae] // Izv. Akad. Nauk Kazakhskoi SSR (Biol.). No.4. P.14-22 [in Russian, with English summary].

Marusik Yu.M., Tarabaev Ch.K. 1991. [Catalogue of orb-weaving spiders (Aranei: Araneidae, Tetragnathidae, Uloboridae) of Kazakhstan. Family Tetragnathidae, Uloboridae]// Izv. Akad. Nauk Kazakhskoi SSR (Biol.). No.2. P.26-28 [in Russian, with English summary].

Mikhailov K.G. 2013. Advances in the study of the spider fauna of Russia and adjacent regions: a 2011 update // Arthropoda Selecta. Vol.22. No.1. P.47-52.

Ovtsharenko V.I., Savelyeva L.G. 1992. [An analysis of the fauna of the spider family Gnaphosidae of Eastern Kazakhstan] // Fauna i ekol. paukov, skorpionov i lozhnoskorpionov SSSR. Tr. Zool. in-ta AN SSSR. T.226. P.131-133 [in Russian].

Ponomarev A.V., Abdurakhmanov G.M., Alieva S.V., Dvadnenko K.V. 2011. [Spiders (Arachnida: Aranei) of coastal and island territories of northern Dagestan] // Yug Rossii: ekologiya, razvitie. Makhachkala. No.4. P.126-143 [in Russian, with English summary].

Savelyeva L.G. 1970. [The fauna and zoogeographical relations of spiders of the East Kazakhstan Area] // Biologiya i Geografiya. Vyp.6. P.78-88 [in Russian].

Savelyeva L.G. 1972a. [New species and subspecies of Clubionidae (Aranei) from East-Kazakhstan Area] // Zool. Zhurnal. Vol.51. Vyp.9. P.1404-1407 [in Russian].

Savelyeva L.G. 1972b. [New species of Gnaphosidae (Aranei) from East-Kazakhstan Area] // Zool. Zhurnal. Vol.51. Vyp.8. P.12381241 [in Russian, with English summary].

Savelyeva L.G. 1972c. [New and little known species of the spider family Lycosidae (Aranei) from East-Kazakhstan Area] // Entomol. Obozr. Vol.51. Vyp.2. P.454-462 [in Russian].

Savelyeva L.G. 1976. [A zonal-stational distribution of spiders in the territory of East Kazakhstan Area] // Biol. nauki. AlmaAta: Kazakh. Ped. In-t. Vol.1. P.50-54 [in Russian].

Savelyeva L.G. 1979. [Zoogeographical complexes of spiders (Aranei) from East Kazakhstan] // Priroda i khoz. Vost. Kazakhstana. Alma-Ata: Nauka. P.139-148 [in Russian].

Savelyeva L.G. 1984. [Enemies of spiders (Aranei) in East Kazakhstan] // Fauna i ekol. paukoobr. Perm: Permsk. Un-t. P.7881 [in Russian].

Tuneva T.K. 2004. A contribution on the gnaphosid spider fauna (Araneae: Gnaphosidae) of east Kazakhstan // Logunov D.V., Penney D. (eds.). European Arachnology 2003 (Proceedings of the 21st European Colloquium of Arachnology, St.-Peterburg, 4-9 August 2003). Arthropoda Selecta. Special Issue. No.1. P.319-332. 
Utochkin A.S., Savelyeva L.G. 1995. Review of the spider genus Xysticus C.L. Koch, 1835 (Arachnida, Aranei, Thomisidae ) in the East Kazakhstan area // Arthropoda Selecta. Vol.4. No.1. P.65-69.
Zonstein S.L. 2009. The spider genus Zaitunia Lehtinen, 1967 (Araneae: Filistatidae) in Israel and Sinai (Egypt). // Israel J. Entomol. Vol.38. P.125-131.

Responsible editor K.G. Mikhailov 